\title{
KUALITAS BAKTERIOLOGIS PERALATAN MAKAN DAN PERILAKU PEDAGANG KAKI LIMA DI SENTRA WISATA JAMBANGAN SURABAYA TAHUN 2016
}

\author{
Emmy Laskar Pratiwi, Umi Rahayu, Winarko
}

\begin{abstract}
Food safety is an effort to control the risk factors of contaminations on food both come from food ingredients, people, places and equipment in order to be safe to consume. The purpose of this study was to determine the Behavior of sidewalk merchants and the bacteriological quality of eating equipments in the Jambangan Tourism Center of Surabaya City.

This research is descriptive research with cross sectional approach. Data collection was by means of observation, interviews and laboratory tests. Total sample of 20 merchants. Data were analyzed descriptively in narrative form and tables.

The results of research showed that the behavior of the food and drink merchants in the Jambangan Sidewalk Merchants Tourism Center of Surabaya as much as $75 \%$ behave good and $25 \%$ behave reasonably. The wipe test results of eating equipments in parameter Escherichia coli if compared with the Decree of Indonesian Health Ministry No. 1098/Menkes/VI/2003 showed that there are two stands positive Escherichia coli.

It can be concluded that from the 20 merchants surveyed, 15 merchants (75\%) behave well, five traders (25\%) behave fairly and on wipe examination of eating tools there are 2 stands positive Escherichia coli. It is recommended in order that merchants apply the personal hygiene and provide 3 sinks for equipments and at drying use a clean cloth specifically for eating and drinking tools.
\end{abstract}

Keywords : Merchant behavior, bacteriological quality, tool wipe

\section{PENDAHULUAN}

Keamanan pangan berdasarkan UndangUndang RI No. 18 Tahun 2012 tentang pangan, adalah kondisi dan upaya untuk mencegah pangan dari kemungkinan cemaran biologis, kimia dan benda lain yang dapat mengganggu, merugikan serta membahayakan kesehatan manusia serta tidak bertentangan dengan agama, keyakinan dan budaya masyarakat sehingga aman dikonsumsi. Keamanan pangan pada dasarnya adalah upaya higene sanitasi makanan, gizi dan safety. Higiene sanitasi makanan dalam Permenkes RI tentang Persyaratan Hygiene Sanitasi Rumah Makan dan Restoran adalah upaya mengendalikan faktor risiko terjadinya kontaminasi terhadap makanan, baik yang berasal dari bahan makanan, orang, tempat dan peralatan makan agar aman dikonsumsi.

Perkembangan jumlah dan jenis tempat pengelolaan makanan (TPM) dari hari kehari makin meningkat seiring berkembangnya sosial ekonomi masyarakat yang menghendaki serba cepat dan praktis. Untuk memenuhi kebutuhan makanan keluarga maupun untuk keperluan jamuan makanan, semakin banyak masyarakat yang memilih beli dari pada memasak sendiri. Gejala ini disatu sisi berdampak positif pada usaha jasa di bidang makanan, penciptaan lapangan kerja dan pertumbuhan ekonomi, namun apabila tidak disertai kewaspadaan terhadap upaya penyehatan makanan yang diproduksi, seringkali dapat menimbulkan gangguan kesehatan, penyakit, keracunan makanan yang bisa berakibat kematian. (Sundari dan Andani, 2002).
Menurut data dari Dinas Kesehatan Propinsi Jawa Timur tahun 2005, Kota Surabaya telah terjadi 5 kasus keracunan yang menyerang 80 orang, yang 2 orang diantaranya meninggal. Dari hasil monitoring KLB keracunan pangan pada tahun 2005, yang dilaporkan oleh BPOM ada 184 kejadian KLB keracunan pangan dengan 23.864 orang jumlah yang makan, 8.949 orang jumlah yang sakit, dan 49 orang yang meninggal dunia. Dari 184 kejadian tersebut, 28 kejadian disebabkan dari makanan olahan, 33 kejadian dari makanan jajanan, 39 kejadian dari makanan jasaboga, 78 kejadian dari masakan rumah tangga, dan 6 kejadian dari makanan lain-lain.

Menurut data dari Dinas Kesehatan Kota Surabaya tahun 2014, dari hasil survei tempat pengelolaan makanan (TPM) menurut status higiene sanitasi di kota Surabaya tahun 2014, jumlah TPM yang ada di kota Surabaya sebanyak 7.016 terdiri dari jasaboga, restoran, rumah makan/ restoran, depot air minum, makanan jajanan/ pedagang kaki lima. Pada makanan jajanan/ pedagang kaki lima yang tidak memenuhi syarat higiene sanitasi sebanyak 5.655 tempat dan yang memenuhi syarat higiene sanitasi sebanyak 1.338 tempat

Alat makan merupakan salah satu faktor yang berperan di dalam penularan penyakit, sebab alat makan yang tidak bersih dan mengandung mikroorganisme dapat menularkan penyakit lewat makanan, sehingga proses pencucian alat makan sangat berarti dalam membuang sisa makanan dari 
peralatan yang menyokong pertumbuhan mikroorganisme yang hidup. Perilaku penjamah makanan ikut berperan dalam menentukan suatu makanan sehat atau tidak, perilaku penjamah makanan juga dapat menimbulkan risiko kesehatan, dalam arti perilaku penjamah makanan yang tidak sehat akan berdampak pada higienitas makanan yang disajikan. Sebaliknya, perilaku penjamah makanan yang sehat dapat menghindarkan makanan dari kontaminasi atau pencemaran dan keracunan. (Jilfer Poli, Henry Palandeng, J. Sinolungan, 2013) diakses pada 11 november 2015. Dari hasil survey pendahuluan yang peneliti lakukan Lokasi sentra wisata pedagang kaki lima Jambangan yang termasuk salah satu destinasi wisata kampung di kota Surabaya sehingga pembeli tidak hanya masyarakat sekitar namun juga para wisatawan. Dari segi hygiene sanitasi masih kurang baik sehingga ingin diketahui apakah ada resiko penularan lewat makanan yang di akibatkan faktor penyajian makanan, peralatan makan dan perilaku pedagang sehingga nantinya dapat di antisipasi melalui kegiatan pencegahan pada proses pencucian dan penyuluhan. Pengawasan terhadap hygiene dan sanitasi makanan dan minuman utamanya adalah usaha diperuntukkan untuk umum seperti restoran, rumah makan, ataupun pedagang kaki lima mengingat bahwa makanan dan minuman merupakan media yang potensial dalam penyebaran penyakit (Depkes RI, 2004).

Berdasarkan latar belakang tersebut menarik untuk diketahui lebih lanjut "Perilaku pedagang kaki lima dan kualitas bakteriologis peralatan makan di Sentra Wisata Jambangan Surabaya tahun 2016" melalui penelitian.

\section{TUJUAN PENELITIAN}

Untuk mengetahui Perilaku pedagang kaki lima dan kualitas bakteriologis peralatan makan di sentra wisata Jambangan kota Surabaya tahun 2016.

\section{METODE PENELITIAN}

Penelitian ini bersifat deskriptif yaitu penelitian yang dilakukan dengan tujuan untuk membuat gambaran atau deskripsi tentang suatu keadaan secara objektif (Soekidjo Notoatmodjo, 2012), dimana penelitian di ditujukan untuk menilai perilaku pedagang dan kualitas bakteriologi peralatan oleh pedagang kaki lima di sentra wisata Jambangan kota Surabaya. Sedangkan desain penelitian ini adalah cross sectional karena pengamatan yang dilakukan hanya sesaat sedangkan obyek yang diteliti terus berkembang dan berubah terus menerus (Soekidjo Notoatmodjo, 2012).Besar sampel penelitian ini adalah total populasi sebanyak 20 pedagang kaki lima yang akan diukur perilakunya melalui wawancara dan pengambilan sampel usap alat makan dan minum meliputi piring, sendok, garpu dan gelas dengan parameter Escherichia coli. Selanjutnya hasil pengukuran dan pemeriksaan laboratorium diolah dan dianalisis secara diskriptif.

\section{HASIL PENELITIAN DAN PEMBAHASAN}

Perilaku pedagang kaki lima di Sentra Wisata Pedagang Kaki Lima (PKL) Jambangan Kota Surabaya

Tabel 1

Tingkat Pengetahuan Pedagang di Sentra Wisata PKL Jambangan Kota Surabaya tahun 2016

\begin{tabular}{clccc}
\hline No. & & Kriteria & \multicolumn{2}{c}{ Prosentase (\%) } \\
\hline 1 & Baik & & 3 & 85 \\
\hline 2 & Cukup & & 0 & 15 \\
\hline 3 & Kurang & & 20 & 0 \\
& & Total & 100 \\
\hline
\end{tabular}

Berdasarkan tabel 1 diatas bahwa tingkat pengetahuan pedagang makanan minuman tentang kebersihan diri, pencucian alat, dan penyajian makanan di Sentra Wisata Pedagang Kaki Lima
(PKL) Jambangan Kota Surabaya baik dan cukup dengan sebaran prosentase $85 \%$ baik dan $15 \%$ cukup

\section{Sikap Pedagang di Sentra Wisata Pedagang Kaki Lima (PKL) Jambangan Kota Surabaya}

Tabel 2

Sikap Pedagang di Sentra Wisata PKL Jambangan Kota Surabaya tahun 2016

\begin{tabular}{llccc}
\hline No. & & Kriteria & $\sum$ Pedagang & Prosentase (\%) \\
\hline 1 & Baik & & 16 & 80 \\
\hline 2 & Cukup & & 4 & 20 \\
\hline 3 & Kurang & & 0 & 0 \\
\hline & & Total & 20 & 100 \\
\hline
\end{tabular}


Berdasarkan tabel 2 bahwa sikap Pedagang makanan minuman tentang hygiene sanitasi makanan di Sentra Wisata Pedagang Kaki
Lima (PKL) Jambangan Kota Surabaya baik dan cukup dengan sebaran prosentase $80 \%$ baik dan $20 \%$ cukup.

\section{Tindakan Pedagang di Sentra Wisata Pedagang Kaki Lima (PKL) Jambangan Kota Surabaya}

Tabel 3

Tindakan Pedagang di Sentra Wisata PKL Jambangan Kota Surabaya tahun 2016

\begin{tabular}{|c|c|c|c|}
\hline No. & Kriteria & $\Sigma$ Pedagang & Prosentase (\%) \\
\hline 1 & Baik & 12 & 60 \\
\hline 2 & Cukup & 8 & 40 \\
\hline 3 & Kurang & 0 & 0 \\
\hline & Total & 20 & 100 \\
\hline
\end{tabular}

Berdasarkan tabel 3 bahwa tindakanPedagang makanan minuman tentang hygiene sanitasi makanan di Sentra Wisata
Pedagang Kaki Lima (PKL) Jambangan Kota Surabaya baik dan cukup dengan prosentase $60 \%$ baik dan $40 \%$ cukup.

\section{Perilaku Pedagang di Sentra Wisata Pedagang Kaki Lima (PKL) Jambangan Kota Surabaya}

Tabel 4

Perilaku Pedagang di Sentra Wisata PKL Jambangan Kota Surabaya tahun 2016

\begin{tabular}{|c|c|c|c|}
\hline No. & Kriteria & $\Sigma$ Pedagang & Prosentase (\%) \\
\hline 1 & Baik & 15 & 75 \\
\hline 2 & Cukup & 5 & 25 \\
\hline 3 & Kurang & 0 & 0 \\
\hline & Total & 20 & 100 \\
\hline
\end{tabular}

Berdasarkan tabel 4 bahwa perilaku Pedagang makanan minuman tentang hygiene sanitasi makanan di Sentra Wisata Pedagang Kaki Lima
(PKL) Jambangan Kota Surabaya baik dan cukup dengan sebaran prosentase $75 \%$ baik dan $25 \%$ cukup.

\section{Kualitas Bakteriologis Alat Makan dan Minum Parameter E. coli}

Tabel 5

Kualitas Bakteriologis Alat Makan dan Minum Parameter E.coli di Sentra Wisata PKL Jambangan Kota Surabaya Tahun 2016

\begin{tabular}{|c|c|c|c|c|c|c|}
\hline \multirow[t]{3}{*}{ NAMA ALAT } & \multicolumn{4}{|c|}{ KUALITAS BAKTERIOLOGI } & \multicolumn{2}{|c|}{ JUMLAH } \\
\hline & \multicolumn{2}{|c|}{+} & \multicolumn{2}{|c|}{ - } & \multirow[t]{2}{*}{$\mathbf{N}$} & \multirow[t]{2}{*}{$\%$} \\
\hline & $\mathbf{N}$ & $\%$ & $\mathbf{N}$ & $\%$ & & \\
\hline Gelas & 2 & 10 & 18 & 90 & 20 & 100 \\
\hline Sendok & 2 & 10 & 18 & 90 & 20 & 100 \\
\hline Garpu & 2 & 10 & 18 & 90 & 20 & 100 \\
\hline Piring & 2 & 10 & 18 & 90 & 20 & 100 \\
\hline JUMLAH & 8 & 10 & 72 & 90 & 80 & 10 \\
\hline
\end{tabular}

Berdasarkan tabel 5 tersebut dapat disimpulkan bahwa seluruh peralatan makan dan minum dari hasil pemeriksaa usap alat menunjukkan $90 \%$ Negatif atau tidak ditemukan $E$. Coli dan hanya $10 \%$ yang positif E. Coli. Hasil positif ditemukan pada stan 4 dan 11.

Keberadaan E. Coli pada peralatan makan akan terus berisiko terjadinya penularan penyakit pada Konsumen bila tidak segera dilakukan pemecahan. Menurut Fardiaz,(1992), bahwa Escherichia coli adalah salah satu bakteri yang tergolong koliform dan hidup secara normal di dalam kotoran manusia ataupun hewan. Escherichia coli yang umumnya menyebabkan diare terjadi di seluruh dunia. Pelekatan pada sel epithelial pada usus kecil atau usus besar sifatnya dipengaruhi oleh gen dalam plasmid. Sama halnya dengan toksin yang merupakan plasmid atau phagemediated (Brooks dkk, 2001 yang dikutip dari pohan, 2009).

Peralatan dapat menjadi kontaminan bagi makanan. Peralatan juga dapat terkontaminasi oleh bakteri Escherichia coli jika dicuci dengan air yang tercemar. Peralatan dapur yang mengalami kontak langsung dengan makanan seharusnya didesain dan diletakkan sedemikian rupa untuk menjamin mutu dan keamanan produk yang dihasilkan sehingga 
dapat mencegah keberadaan $E$. Coli pada peralatan makan dan minuman dapat berasal dari sumber air yang digunakan maupun akibat kontaminasi penjamah makanan pada saat penyajian.

\section{Hubungan Antara Tingkat Pengetahuan Pedagang Dengan Kualitas Bakteriologis Peralatan Makan dan Minum}

Tabel 6

\begin{tabular}{|c|c|c|c|c|c|c|}
\hline \multirow[t]{3}{*}{ Tingkat Pengetahuan } & \multicolumn{4}{|c|}{ Kualitas Bakteriologis } & \multirow{2}{*}{\multicolumn{2}{|c|}{ Jumlah }} \\
\hline & \multicolumn{2}{|c|}{ Memenuhi Syarat } & \multicolumn{2}{|c|}{ Tdk Memenuhi Syarat } & & \\
\hline & $\mathbf{N}$ & $\%$ & $\mathbf{N}$ & $\%$ & $\mathbf{N}$ & $\%$ \\
\hline Baik & 16 & 94.1 & 1 & 5.9 & 17 & 100 \\
\hline Cukup & 2 & 66.7 & 1 & 33.3 & 3 & 100 \\
\hline Kurang & 0 & 0 & 0 & 0 & 0 & 0 \\
\hline Jumlah & 18 & 90 & 2 & 10 & 20 & 100 \\
\hline
\end{tabular}

Hubungan Antara Tingkat Pengetahuan PedagangDengan Kualitas Bakteriologis Peralatan Makan dan Minum di Sentra Wisata PKL Jambangan Kota Surabaya Tahun 2016

Berdasarkan tabel 6 tersebut di atas diketahui bahwa Pedagang yang mempunyai tingkat pengetahuan baik $94.1 \%$ kualitas bakteriologis peralatan makan memenuhi syarat, sedangkan pada Pedagang yang mempunyai tingkat pengetahuan cukup hanya $66.7 \%$ kualitas bakteriologis peralatan makan memenuhi syarat dan pada Pedagang yang memiliki tingkat pengetahuan cukup sebesar $33.3 \%$ dibanding dengan yang memiliki tingkat pengetahuan baik, yaitu $5.9 \%$, sehingga dapat disimpulkan bahwa secara diskripsitif nampaknya ada hubungan antara tingkat pengetahuan Pedagang dengan kualitas bakteriologis peralatan makan dan minum pada di Sentra PKL Jambangan Kota Surabaya.

Pengawasan terhadap tempat penyajian makanan dan minuman (TPM) yang merupakan tugas dari bagian Kesehatan Lingkungan di Puskesmas antara lain melalui : 1) Pembinaan dan pengambilan sampel makanan terhadap TPM,

\section{Hubungan Antara Sikap Pedagang Dengan Kualitas Bakteriologis Peralatan Makan dan Minum}

Tabel 7

Hubungan Antara SikapPedagangDengan Kualitas Bakteriologis Peralatan Makandan Minum di Sentra Wisata PKL Jambangan Kota Surabaya Tahun 2016

\begin{tabular}{|c|c|c|c|c|c|c|}
\hline \multirow[t]{3}{*}{ Sikap Pedagang } & \multicolumn{4}{|c|}{ Kualitas Bakteriologis } & \multirow{2}{*}{\multicolumn{2}{|c|}{ Jumlah }} \\
\hline & \multicolumn{2}{|c|}{ Memenuhi Syarat } & \multicolumn{2}{|c|}{ Tdk Memenuhi Syarat } & & \\
\hline & $\mathbf{N}$ & $\%$ & $\mathbf{n}$ & $\%$ & $\mathbf{N}$ & $\%$ \\
\hline Baik & 16 & 100 & 0 & 0 & 16 & 100 \\
\hline Cukup & 2 & 50 & 2 & 50 & 4 & 100 \\
\hline Kurang & 0 & 0 & 0 & 0 & 0 & 0 \\
\hline Jumlah & 18 & 90 & 2 & 10 & 20 & 100 \\
\hline
\end{tabular}

Berdasarkan tabel 7 tersebut di atas diketahui bahwa Pedagang yang mempunyai sikap baik 100 $\%$ kualitas bakteriologis peralatan makan memenuhi syarat, sedangkan pada Pedagang yang mempunyai sikap cukup $50 \%$ kualitas bakteriologis peralatan makan memenuhi syarat. Sebaliknya kualitas bakteriologis peralatan makanan dan diantaranya rumah makan / restoran, jasa boga, industri rumah tangga, makanan jajanan, pelatihan dan penyuluhan terhadap pengelola TPM, pembinaan terhadap tempat pengisisian air minum isi ulang, dan 2) Melaksanakan kursus pengolahan makanan dan minuman kepada pengelola TPM di lingkungan Puskesmas.

Menurut Kementrian Kesehatan RI tahun 2012 tentang kursus higiene sanitasi makanan dan minuman menjelaskan bahwa kebersihan penjamah makanan higiene perorangan (Personal Hygiene) merupakan kunci keberhasilan dalam pengolahan makanan yang aman dan sehat. Prinsip higiene perorangan atau yang disebut juga dengan kebersihan diri, dalam penerapannya adalah: 1) Mengetahui sumber cemaran dari tubuh, 2) Sumber cemaran karena perilaku, 3) Sumber karena ketidaktauan dan 4) Perlakuan-perlakuan yang perlu dikerjakan untuk mencegah pencemaran. 
bakteriologis peralatan makan dan minum pada di Sentra PKL Jambangan Kota Surabaya.

Dari hasil penilaian sikap yang dilakukan peneliti di temukan sikap pedagang kaki lima yang tidak sesuai standart karena masih menggunakan 2 (dua) buah bak air untuk pencucian peralatan. Bak tersebut digunakan sebagai bak pencucian dan bak pembilasan.

\section{Hubungan Antara Tindakan Pedagang Dengan Kualitas Bakteriologis Peralatan Makan dan Minum}

Tabel 8

Hubungan Antara TindakanPedagangDengan Kualitas Bakteriologis Peralatan Makandi Sentra Wisata PKL Jambangan Kota Surabaya Tahun 2016

\begin{tabular}{lcccccc}
\hline \multirow{2}{*}{ Tindakan Pedagang } & \multicolumn{4}{c}{ Kualitas Bakteriologis } & & \multicolumn{2}{c}{ Jumlah } \\
\cline { 2 - 6 } & \multicolumn{1}{c}{ Memenuhi Syarat } & Tdk Memenuhi Syarat & & $\mathbf{~}$ \\
\cline { 2 - 6 } & $\mathbf{n}$ & $\mathbf{\%}$ & $\mathbf{n}$ & $\mathbf{\%}$ & $\mathbf{N}$ & 100 \\
\hline Baik & 12 & 100 & 0 & 0 & 12 & 100 \\
\hline Cukup & 6 & 75 & 2 & 25 & 8 & 0 \\
\hline Kurang & 0 & 0 & 0 & 0 & 0 & 100 \\
\hline Jumlah & 18 & 90 & 2 & 10 & 20 & \\
\hline
\end{tabular}

Berdasarkan tabel 8 tersebut di atas diketahui bahwa Pedagang yang mempunyai tindakan baik $100 \%$ kualitas bakteriologis peralatan makan memenuhi syarat, sedangkan pada Pedagang yang mempunyai tindakan cukup $75 \%$ kualitas bakteriologis peralatan makan memenuhi syarat. Sebaliknya kualitas bakteriologis peralatan makanan dan minum yang tidak memenuhi syarat lebih banyak ditemukan pada Pedagang yang memiliki tindakan cukup sebesar 25 $\%$ dibanding dengan yang memiliki tingkat pengetahuan baik, yaitu $0 \%$. Pada peneltian ini didapatkan hasil bahwa ada hubungan antara tindakan Pedagang dengan kualitas bakteriologis peralatan makan dan minum di Sentra PKL Jambangan Kota Surabaya.

Seperti halnya tingkat pengetahuan dan sikap Pedagang yang sebagian besar baik, hal ini dikarenakan pedagang belum memenuhi persyaratan hygiene sanitasi seperti mencuci tangan dengan sabun setiap kontak dengan makanan, mencuci tangan dengan sabun sebelum

\section{Hubungan Antara PerilakuPedagangDengan Kualitas Bakteriologis Peralatan Makan dan Minum}

Tabel 9

Hubungan Antara Perilaku Pedagang Dengan Kualitas Bakteriologis Peralatan Makan di Sentra Wisata PKL Jambangan Kota Surabaya Tahun 2016

\begin{tabular}{|c|c|c|c|c|c|c|}
\hline \multirow[t]{3}{*}{ Perilaku Pedagang } & \multicolumn{4}{|c|}{ Kualitas Bakteriologis } & & \\
\hline & \multicolumn{2}{|c|}{ Memenuhi Syarat } & \multicolumn{2}{|c|}{ Tdk Memenuhi Syarat } & \multicolumn{2}{|c|}{ Jumlah } \\
\hline & $\mathbf{N}$ & $\%$ & $\mathbf{N}$ & $\%$ & $\mathbf{N}$ & $\%$ \\
\hline Baik & 15 & 100 & 0 & 0 & 15 & 100 \\
\hline Cukup & 3 & 60 & 2 & 40 & 5 & 100 \\
\hline Kurang & 0 & 0 & 0 & 0 & 0 & 0 \\
\hline Jumlah & 18 & 90 & 2 & 10 & 20 & 100 \\
\hline
\end{tabular}

dan seusai mengolah makanan, mencuci tangan dengan sabun setelah buang air besar. Namun, tidak ada penyaji makanan yang mencuci tangan dengan sabun setelah memegang uang. (Agustina dkk, 2009).

Kondisi ini akan bisa berpengaruh terhadap kualitas bakteriologi peralatan makan. Dari hasil penelitian usap alat makan menunjukan 90\% Negatif atau tidak ditemukan E.coli dan hanya $10 \%$ yang positif E.coli yaitu pada stand 4 dan stand 11 . Hal ini disebabkan bahwa sikap yang sudah baik tidak secara otomatis akan mengambarkan tindakan yang baik pula.Menurut Soekidjo Notoatmodjo (2007) dalam teori perilaku dijelaskan bahwa suatu sikap belum otomatis terwujud dalam suatu tindakan (overt behavior). Untuk mewujudkan sikap menjadi suatu perbedaan nyata diperlukan faktor pendukung atau suatu kondisi yang memungkinkan, antara lain adalah fasilitas.Disamping faktor fasilitas juga diperlukan faktor dukungan (support) dari pihak lain. 
Berdasarkan tabel 9 tersebut di atas diketahui bahwa Pedagang yang mempunyai tindakan baik $100 \%$ kualitas bakteriologis peralatan makan memenuhi syarat, sedangkan pada Pedagang yang mempunyai tindakan cukup $60 \%$ kualitas bakteriologis peralatan makan memenuhi syarat. Sebaliknya kualitas bakteriologis peralatan makanan dan minum yang tidak memenuhi syarat lebih banyak ditemukan pada Pedagang yang memiliki perilaku cukup sebesar $40 \%$ dibanding dengan yang memiliki perilaku baik, yaitu $0 \%$. Pada peneltian ini didapatkan hasil bahwa ada hubungan antara perilaku Pedagang dengan kualitas bakteriologis peralatan makan dan minum pada di Sentra PKL Jambangan Kota Surabaya.

Keberadaan Escherichia colivalau hanya $5,9 \%$ berisiko kepada konsumen. Menurut Nurwantoro dkk, (1997) yang dikutip dari pohan, 2009) bahwa Escherichia coli penyebab penyakit pada manusia disebut Entero pathogenic Escherichia coli (EPEC). Dosis infektif EPEC 1081010 sel mampu menimbulkan enterotoksigeni. Ada dua golongan Escherichia coli penyebab penyakit pada manusia.Golongan pertama disebut Entero ToxigenicEschericia coli (ETEC) yang mampu menghasilkan enterotoksin dalam usus kecil dan menyebabkan penyakit dengan gejala diare, muntah-muntah, dehidrasi serupa dengan kolera. Waktu inkubasi penyakit ini 8-24 jam.

Di Sentra Wisata PKL Jambangan Surabaya seluruh pedagang masih menggunakan 2 bak pencucian hal ini tidak sesuai standart. Berdasarkan Kepmenkes RI No 1098/MENKES/SK/VII/2003 bak pencucian sedikitnya terdiri dari 3 bak pencuci yaitu mengguyur, menyabun, dan membilas. Setelah dilakukan pencucian peralatan disimpan dengan baik, yaitu letakkan di rak khusus dan penyimpanan harus terbalik penelitian ini sesuai dengan penelitian yang dilakukan oleh Budi Hartono dan Dewi Susanna (2003) menyatakan bahwa penempatan piring pada tempat terbuka akan dapat memberi kontribusi terhadap kontaminasi silang bakteri pada makanan.

Cara pencucian dan penyimpanan perlatan harus sesuai dengan ketentuan yang berlaku agar peralatan selalu dalam keadaan bersih sebelum digunakan karena cemaran yang tertinggal akibat

\section{DAFTAR PUSTAKA}

Augustin, Elfira, 2014. Gambaran Pengetahuan, Sikap, dan Tindakan Hygiene Sanitasi Pedagang Jajanan Di Sekolah Dasar Cipinang Besar Utara Kotamadya Jakarta Timur Tahun 2014. Diakses pada 11 november 2015

Cahyaningsih, Chairini Tri, dkk., 2009. Hubungan Higiene Sanitasi dan Perilaku Penjamah Makanan dengan Kualitas Bakteriologis Peralatan Makan di Warung Makan. Diakses pada 11 november 2015

Ditjen PP dan PL, 2008 .Pedoman Teknis Penyelenggaraan Hygiene dan Sanitasi pencucian peralatan kurang baik akan menjadi media pertumbuhan mikroorganisme akibatnya dapat mengkontaminasi makanan. Selain itu perilaku pedagang kaki lima berperan penting untuk mencegah terjadinya cemaran biologi, fisika dan kimia karena masih banyak ditemukan pedagang yang merokok, makan dan minum saat bekerja, memakai pakaian bersih dan rapi.

\section{KESIMPULAN DAN SARAN Kesimpulan}

Bardasarkan hasil penelitian dapat disimpulkan bahwa 1) Pengetahuan Pedagang makanan dan minuman di Sentra Wisata Pedagang Kaki Lima (PKL) Jambangan Kota Surabaya prosentase $85 \%$ baik dan $15 \%$ cukup; 2) Sikap Pedagang makanan dan minuman di Sentra Wisata Pedagang Kaki Lima (PKL) Jambangan Kota Surabaya $80 \%$ baik dan 20 \% cukup; 3) TindakanPedagang makanan dan minuman di Sentra Wisata Pedagang Kaki Lima (PKL) Jambangan Kota Surabaya $60 \%$ baik dan 40 $\%$ cukup; 4) Perilaku Pedagang makanan dan minuman di Sentra Wisata Pedagang Kaki Lima (PKL) Jambangan Kota Surabaya $75 \%$ baik dan 25 \% cukup.; 5) Kualitas bakteriologi peralatan makan dan minum di Sentra Wisata Pedagang Kaki Lima (PKL) Jambangan Kota Surabaya $90 \%$ memenuhi syarat dan $10 \%$ tidak memenuhi syarat; dan 6) Ada hubungan antara perilaku Pedagang dengan kualitas bakteriologis peralatan makan dan minum di Sentra PKL Jambangan Kota Surabaya.

\section{Saran}

Saran pada penelitian ini ditujukan 1) Pedagang, agar menerapkan kebersihan perseorangan, tidak merokok, berbicara saat menangani makanan, menyediakan 3 bak pencucian dan mengunakan lap yang bersih tdan idak di campur dengan lap untuk meja; 2) Bagi Puskesmas, perlu meningkatkan lagi pembinaan dan pengawasan yang sudah dilakukan di ikuti dengan pengambilan sampel usap alat makan dan minum; dan 3) Bagi Peneliti lain,perlu dilakukan penelitian lebih lanjut terkait dengan variabel yang belum diteliti, yaitu kualitas bakteriologis air yang berkontribusi dalam pencemaran.

Makanan Jajanan. Jakarta : Departemen Kesehatan

Dit. Hygiene Makanan dan Minuman P3M Depkes RI, 1981. Pengawasan dan Persyaratan Hygiene dan Sanitasi Tempat-Tempat Pembuatan dan Penjualan Makanan dan Minuman (TP2M) di Indonesia. Akademi Penilik Kesehatan

Ditjen PP dan PL, 2012. Kumpulan Modul Khursus Hygiene Sanitasi Makanan dan Minuman. Jakarta : Departemen Kesehatan 
Ditjen PPM dan PL, 2004. Kumpulan Modul Khusus Hygiene Sanitasi Makanan dan Minuman. Jakarta : department Kesehatan

Febria Agustina, dkk, 2009, Higiene dan Sanitasi Pada Pedagang JajananTradisional diLingkungan Sekolah Dasar di Kelurahan Demang LebarDaun Palembang Tahun 2009. Diakses 10Mei 2016

Keputusan Menteri Kesehatan RI nomor 1098/MENKES/SK/VII/2003. Tentang Persyaratan Hygiene Sanitasi Rumah Makan Dan Restoran.

Mundiatun dan Daryanto, 2015. Pengelola Kesehatan Lingkungan. Jakarta : 2015

Notoatmodjo, Soekidjo. 2007. Kesehatan Masyarakat IImu Dan Seni. Jakarta: Rineka Cipta. Cetakan pertama

Notoatmodjo, Soekidjo. 2015. Metodologi Penelitian Kesahatan. Jakarta: Rineka Cipta

Pemerintahan Provinsi Jawa Timur Dinas Kesehatan, 2015. Hygiene Sanitasi Makanan Jajanan. Jakarta : 2015

Pohan S. Desmaslima, 2009. Pemeriksaan Escherichia coli pada usapan peralatan makan yang digunakan oleh pedagang makanan di pasar petisan medan. Diakses 10 Mei 2016
Poli, Jilfer, dkk., 2013. Hubungan Antara Perilaku Penjamah Makanan Dengan Angka Kuman Pada Peralatan Makan Di Warung Makan Kawasan Pantai Malalayang Kota Manado. Diakses pada 20 november 2015

Purnawijayanti, H., 2001, Sanitasi, Higiene dan Keselamatan Kerja dalamPengolahan Makanan, Yogyakarta: Kanisius. Diakses pada 10 Mei 2016

Rahayu, Nunik Agustin, 2013. Hubungan Hygiene Dan Sanitasi Pada Alat Pengolah Makanan Gado-Gado Di Lingkungan Pasar Johar Kota Semarang Tahun 2012. Diakses pada 11 november 2015

Sugiyono, 2014. Metode Penelitian Kuantitatif, Kualitatif dan R\&D. Bandung: Alfabeta, CV.

Sundari, S., dan Ellyandari, 2002. Hygiene Sanitasi Makanan (HSM-B). Surabaya, PoliteknikKesehatan Depkes Surabaya Jurusan Kesehatan Lingkungan Suraya : 2002

Widoyoko Eko Putro Prof.Dr.S. Teknik Penyusunan Instrumen Penelitian. Buku Beta:2012 